\title{
MILLEPORA LICHENOIDES.
}

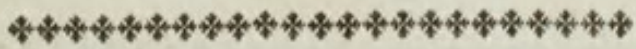

Character Genericus .

Animal Hydra.

Corallium poris turbinatis teretibus.

$$
\text { Lin. Syf. Nat. p. 1282. }
$$

CHARACTER SPECIFICUS.

MILLEPORA caulefcens decumbens bifarie dichotoma, ramis denticulatis binis porofis fcabris.

$$
\text { Lin. Syft. Nat. p. } 1283 .
$$

MILLEPORA tubipora.

Soland. et Ell. zooph. p. 139. pl. 26. f. 1.

Formofi corallii in mari mediterraneo generati naturalem magnitudinem depingi curavimus. Color communis flavefcit pallidiffimo-fufcus 


\section{LICHEN MILLEPORE.}

-

\section{GENERIC CHARACTER.}

Animal refembling a Hydra or Polype.

Coral furnifhed with cylindric turbinated pores.

\section{SPECIFIC CHARACTER, EC.}

Caulefcent bifarioufly-dichotomous MILLEPORE, with denticulated porous branches. Tubulous MILLEPORE.

Soland and Ellis zooph. p. 139. pI. 26. f. I.

This beautiful Coral is a native of the Mediterranean fea, and is reprefented on the plate in its natural fize. Its general color is an extremely pal whitifh or yellowifh brown. 


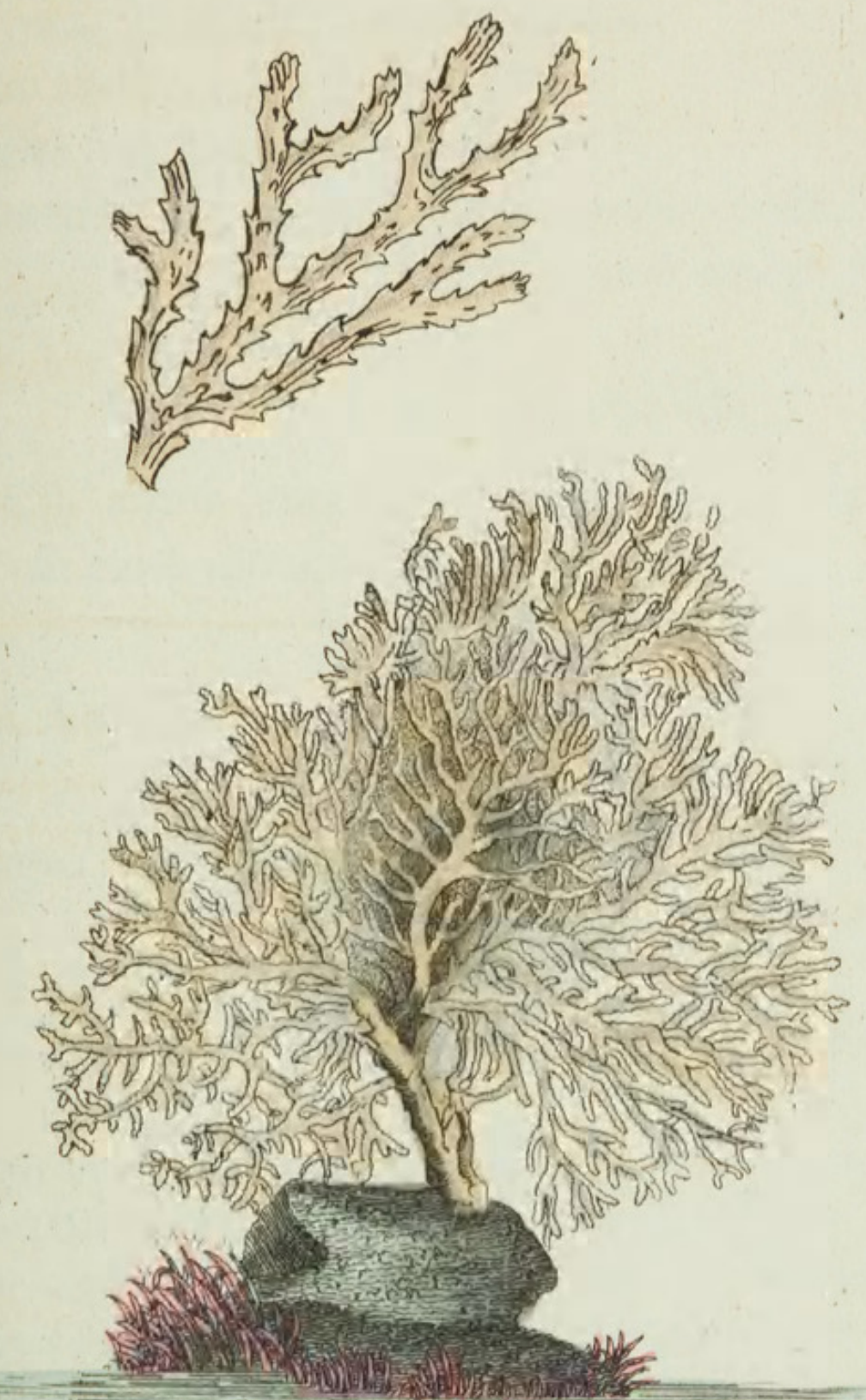

416 


\section{$2 \mathrm{BHL}$ Biodiversity Heritage Library}

Shaw, George. 1800. "Lichen Millepore, Millepora lichenoides [PI. 416]." The Naturalist's Miscellany 11(CXXVI), https://doi.org/10.5962/p.310863.

View This Item Online: https://www.biodiversitylibrary.org/item/276496

DOI: https://doi.org/10.5962/p.310863

Permalink: https://www.biodiversitylibrary.org/partpdf/310863

\section{Holding Institution}

Museums Victoria

\section{Sponsored by}

Atlas of Living Australia

\section{Copyright \& Reuse}

Copyright Status: Public domain. The BHL considers that this work is no longer under copyright protection.

This document was created from content at the Biodiversity Heritage Library, the world's largest open access digital library for biodiversity literature and archives. Visit BHL at https://www.biodiversitylibrary.org. 